\title{
PKM Kelompok Ibu Menyusui dalam Peningkatan Keterampilan Olah Pangan sebagai Penunjang Kualitas ASI
}

\author{
Diyan Indriyani" ${ }^{\# 1}$, Awatiful Azza*2 \\ \#1 Jurusan Keperawatan, Fakultas Ilmu Kesehatan Universitas Muhammadiyah Jember \\ ${ }^{1}$ diyanindriyani@unmuhjember.ac.id \\ *2Jurusan Keperawatan, Fakultas Ilmu Kesehatan Universitas Muhammadiyah Jember \\ 2awatiful.azza@unmuhjember.ac.id
}

\begin{abstract}
Mitra merupakan kelompok ibu menyusui yang tinggal di wilayah Dusun Purwojati dan Dusun Dukuh, Desa Dukuhdempok Kecamatan Wuluhan Kabupaten Jember. Tujuan utama dari pelaksanaan program PKM yang berjudul "PKM Kelompok Ibu Menyusui Dalam Peningkatan Keterampilan Olah Pangan Sebagai Penunjang Kualitas ASI" ini adalah untuk mengatasi permasalahan Mitra berupa: 1) belum optimalnya pemahaman Mitra tentang manajemen laktasi., 2) belum optimalnya pemahaman Mitra tentang pentingnya kualitas nutrisi masa laktasi, 3) kurangnya keterampilan olah pangan Mitra dalam meningkatkan kualitas ASI, 4) kurangnya pengetahuan Mitra menjadi edukator sebaya, dan 5) kurangnya pemahaman Mitra untuk menjadi pendamping dalam edukator sebaya. Solusi untuk permasalahan yang dihadapi Mitra tersebut, perlu dilakukan tindakan berupa: 1) melakukan penyuluhan tentang manajemen laktasi, 2) melakukan penyuluhan tentang pentingnya nutrisi masa laktasi, 3) pelatihan keterampilan olah pangan dalam menunjang kualitas ASI, 4) pelatihan Mitra menjad edukator sebaya dan 5) pelatihan Mitra menjadi pendamping dalam edukator sebaya. Selanjutnya target kegiatan ini adalah kelompok ibu menyusui memiliki persepsi yang tepat dan kemampuan olah pangan dalam menunjang kualitas ASI. Jangka waktu pelaksanaan kegiatan PKM ini selama 8 bulan. Metode pendekatan yang ditawarkan untuk menyelesaikan persoalan mitra program PKM Kelompok ibu menyusui dalam peningkatan keterampilan olah pangan sebagai penunjang kualitas ASI dengan tahapan yaitu: 1) melakukan koordinasi dalam mengumpulkan ibu menyusui, 2) melakukan koordinasi dengan kader kesehatan., 3) melakukan sosialisasi pengetahuan dan pemahaman yang mendalam pada kelompok ibu menyusui tentang manajemen laktasi., 4) melakukan Sosialisasi pengetahuan dan pemahaman pada kelompok ibu menyusui tentang pentingnya kualitas nutrisi masa laktasi, 5) melakukan Pelatihan keterampilan olah pangan dalam meningkatkan kualitas ASI, 6) melakukan Sosialisasi pengetahuan dan pemahaman menjadi edukator sebaya dan 7) melakukan Sosialisasi pengetahuan dan pemahaman menjadi pendamping dalam edukator sebaya.
\end{abstract}

Keywords - ASI, Menyusui, Olah Pangan, Lele

\section{Pendahuluan}

Air Susu Ibu (ASI) merupakan makanan utama bagi bayi terutama saat berusia 0-6 bulan. Kondisi ini menjadi sangat penting bahwa ibu menyusui harus memiliki kualitas ASI yang baik, karena makanan bayi tersebut sangat tergantung dari makanan ibu yang membentuk kualitas ASI. Bila kualitas ASI baik, maka sangat dimungkinkan ibu bisa memberikan ASI secara eksklusif, yaitu bayi hanya diberi ASI saja sampai usia 6 bulan (Hamilton, 2010).

Namun kondisi pemberian ASI eksklusif ini kadang masih mengalami kendala, karena kualitas ASI yang tidak mendukung untuk dapat dipertahankan sampai batas waktu 6 bulan. Selain itu ibu menyusui kadang masih belum memiliki pemahaman yang optimal dalam mengelola ASI dan meningkatkan kualitas ASI, yang salah satunya dengan penunjang berupa nutrisi yang memadai dan syarat akan gizi (Indriyani, Asmuji dan Wahyuni, 2016). Data identifikasi menunjukkan bahwa cakupan ASI eksklusif di wilayah Mitra masih tergolong rendah, yaitu di Dusun Purwojati hanya 32\% dan di Dusun Dukuh hanya sebesar $37 \%$.
Jumlah cakupan ASI eksklusif ini sangat jauh dari harapan pemerintah (Dinas Kesehatan Kabupaten Jember, 2015). Menurut Anggorowati dan Nuzulia (2013) bahwa kondisi rendahnya cakupan ASI eksklusif ini salah satu faktornya adalah ketidakcukupan ASI dan ibu menyusui kurang mampu mempertahankan ASI dalam memenuhi kebutuhan bagi bayi usia 0-6 bulan atau lebih.

Mitra merupakan kelompok ibu menyusui yang tinggal di wilayah Dusun Purwojati dan Dusun Dukuh, Desa Dukuhdempok Kecamatan Wuluhan Kabupaten Jember yang sebagiannya memiliki kebiasaan selama menyusui mengkonsumsi makanan sederhana, kurang bervariasi, komposisi gizi belum berimbang terutama yang mengandung unsur protein. Mitra di kedua wilayah tersebut masih cenderung mayoritas menggunakan protein nabati dalam unsur gizinya seperti tahu tempe. Hal ini karena bahan tersebut dianggap cukup aman di konsumsi selama periode menyusui. Selain itu Mitra merasa kurang optimal minatnya menggunakan protein hewani sebagai penunjang unsur gizi yang sangat penting pada masa menyusui, karena 
dinataranya masih terpengaruh oleh kultur, juga minat konsumsi nya belum optimal karena bahan tersebut hanya cenderung digoreng saja.

Selain itu Mitra juga belum memiliki keterampilan serta pengetahuan yang optimal dalam hal bagaimana mengolah bahan makanan sumber protein tinggi dari bahan dasar yang bersifat mudah didapat, murah serta mengandung unsur protein tinggi yang sangat diperlukan bagi ibu menyusui, salah satunya yaitu bahan dasar misalnya ikan lele. Kondisi tersebut membentuk perilaku Mitra cenderung memilih bahan protein nabati dibandingkan hewani. Perilaku konsumsi protein yang belum optimal ini dapat berakibat asupan nutrisi menjadi tidak seimbang. Sementara pada masa menyusui sangat diperlukan semua unsur gizi secara seimbang, salah satunya adalah unsur protein.

Dampak dari ketidakseimbangan nutrisi pada masa menyusui ini secara umum dapat mengakibatkan masalah kesehatan bagi bayi, dan secara khusus bisa berdampak antara lain: kualitas ASI tidak optimal, gizi pada bayi belum tercukupi, rentannya kondisi kesehatan bayi, terhambatnya pertumbuhan bayi dan lain-lain. Bila kesehatan bayi terganggu maka akan sangat berisiko adanya kondisi sakit pada bayi bahkan bisa sampai terjadi risiko kematian (Indriyani dan Azza, 2017). Oleh karena itu sangat diperlukan adanya solusi yang mengarah kepada terwujudnya kualitas ASI yang baik bagi Mitra, dengan cara memahami tentang manajemen laktasi, meningkatkan keterampilan dalam mengolah bahan makanan sumber protein untuk menunjang kualitas ASI dengan bahan dasar yang mudah dan murah didapat misalnya salah satunya adalah bahan dasar ikan lele. Kelebihan ikan lele adalah selain mudah didapat serta murah, lele memiliki cita rasa yang lezat, tinggi protein dan asam amino omega 3, rendah lemak, mengandung kadar fosfor, magnesium,zink, kalsium, zat besi dan kalium cukup tinggi ( porsi ikan lele mengandung 15,6 gram protein), sumber vitamin B12 (porsi lele sudah memenuhi kebutuhan $40 \%$ vitamin B 12), rendah merkuri, sehinga sangat tepat diberikan untuk ibu yang sedang menyusui juga dapat sebagai penunjang penyembuhan luka bagi ibu menyusui karena dampak dari persalinan (Alodokter, 2015). Berdasarkan paparan di atas dan hasil diskusi dengan Mitra maka dapat diungkapkan bahwa Mitra memiliki masalah tentang belum optimalnya keterampilan ibu menyusui dalam olah pangan yang menunjang kualitas ASI. Hal ini perlu dilakukan intervensi sebagai solusi untuk membantu mengatasi permasalahan Mitra yang fokusnya dalam mengoptimalkan kualitas ASI

\section{TARGET DAN LUARAN YANG DICAPAI}

Target luaran yang diharapkan dalam kegiatan PKM ini adalah Persepsi ibu menyusui di kedua Mitra tentang manajemen laktasi meningkat dan tepat, persepsi pentingnya kualitas nutrisi masa laktasi tepat, memiliki perilaku olah pangan yang bervariasi dengan bahan dasar ikan lele untuk menunjang makanan tinggi protein, mampu menjadi edukator sebaya bagi anggota kelompoknya.

\section{III.METODE PELAKSANAAN}

\section{A. Tahap Persiapan}

- Pengurusan administrasi/perijinan ke Bakesbang dan Linmas Kabupaten Jember, kemudian diteruskan ke Dinas Kesehatan Kabupaten Jember. Setelah itu ditindaklanjuti ke Dusun Purwojati dan Dusun Dukuh Desa Dukuhdempok Kecamatan Wuluhan Kabupaten Jember

- Koordinasi antara tim kerja dengan mitra untuk mempersiapkan segala sesuatu yang diperlukan (jadual kegiatan, tempat kegiatan, media yang akan digunakan, dan bagaimana kegiatan nanti akan dilakukan)

\section{B. Tahap Pelaksanaan}

- Melakukan Koordinasi dalam mengumpulkan ibu menyusui

- Melakukan Koordinasi dengan kader kesehatan.

- Melakukan Sosialisasi pengetahuan dan pemahaman yang mendalam pada kelompok ibu menyusui tentang manajemen laktasi.

- Melakukan Sosialisasi pengetahuan dan pemahaman pada kelompok ibu menyusui tentang pentingnya kualitas nutrisi masa laktasi

- Melakukan Pelatihan keterampilan olah pangan dalam meningkatkan kualitas ASI

- Melakukan Sosialisasi pengetahuan dan pemahaman menjadi edukator sebaya.

- Melakukan Sosialisasi pengetahuan dan pemahaman menjadi pendamping dalam edukator sebaya.

\section{Tahap Evaluasi}

1) Evaluasi proses kegiatan: Kegiatan yang dilakukan pada tahap ini adalah melakukan evaluasi terhadap proses kegiatan PKM mulai dari awal sampai dengan akhir.

2) Evaluasi hasil kegiatan: Evaluasi hasil diharapkan dapat mengetahui tingkat capaian tujuan PKM antara lain: pemahaman tentang manajemen laktasi, pemahaman tentang pentingnya nutrisi bagi kualitas ASI, keterampilan olah pangan dalam menunjang kualitas ASI, kemampuan menjadi edukator sebaya, kemampuan menjadi pendamping edukator sebaya.

3) Evaluasi dampak kegiatan: Evaluasi dampak kegiatan adalah dengan melihat efek kegiatan yang dilihat dari kemampuan ibu menyusui dalam melakukan olah pangan yang menunjang kualitas ASI, maka bayi menjadi sehat, dan dapat mengurangi kemungkinan sakit termasuk risiko kematian pada bayi.

\section{IV.HASIL DAN PEMBAHASAN}

Kegiatan PKM ini difokuskan pada kelompok ibu menyusui yang ada di di wilayah Dusun Purwojati dan Dusun Dukuh, Desa Dukuhdempok Kecamatan Wuluhan 
Kabupaten Jember yang menghadapi masalah upaya peningkatan kualitas ASI. Adapun kegiatannya dilaksanakan sebagai berikut:

\section{A. Persiapan dan Perijinan}

Tim pelaksana melakukan persiapan pelaksanaan PKM secara tehnis dan operasional agar mudah dalam proses pelaksanaannya. Hal ini dilakukan dengan cara koordinasi dengan Ketua LPPM Universitas Muhammadiyah Jember. Selain hal tersebut Tim Pelaksana juga melengkapi segala hal yang berkaitan dengan kelengkapan literatur guna menunjang dalam proses implementasi program. Tim pelaksana meminta ijin untuk pelaksanaan PKM Kelompok Ibu Menyusui Dalam Peningkatan Keterampilan Olah Pangan Sebagai Penunjang Kualitas ASI di Desa Dukuhdempok, Kecamatan Wuluhan, Kabupaten Jember Propinsi Jawa Timur ini dengan mengajukan permohonan ijin dari Fakultas Ilmu Kesehatan (tanggal 09 April 2018) ke Bakesbangpol Kabupaten Jember. Berdasarkan surat ijin dari Bakesbangpol yang telah didapatkan yaitu tanggal 25 April 2018 tim Pelaksana melanjutkan rekomendasi ijin ke Kepala Dinas Kesehatan Kabupaten Jember. Hasil ijin dari Ka. Dinkes Kabupaten Jember tanggal 30 April 2018 tersebut berupa kelanjutan surat ke Puskesmas Wuluhan Kabupaten Jember.

\section{B. Melakukan Koordinasi dalam mengumpulkan ibu menyusui}

Tim pelaksana telah mengundang Mitra I dan Mitra II dalam rangka melakukan koordinasi untuk pelaksanaan program PKM yang dilaksanakan tanggal 3 Mei 2018. Hadir dalam kegiatan tersebut Ketua Kader Posyandu wilayah Dukuh dan Ketua Kader Posyandu Wilayah Purwojati yang disertai dengan ibu menyusui dari masingmasing wilayah berjumlah 6 orang (total 12 ibu menyusui dari Mitra I dan Mitra II). Pada koordinasi tersebut disepakati bahwa untuk kegiatan pertemuan setiap implementasi program bertempat di Wilayah Wuluhan Jember, dengan alasan karena tempat, fasilitas dan lokasinya memudahkan bagi Mitra I dan Mitra II untuk melaksanakannya. Selain hal tersebut bersama tim pelaksana bersama Mitra juga menyusun jadwal pelaksanaan kegiatan sampai selesai.

\section{Melakukan Koordinasi dengan kader kesehatan.}

Ketua pelaksana bersama team melakukan koordinasi lanjutan tanggal 4 Mei 2018 dengan kader kesehatan di wilayah Dukuh dan Purwojati untuk melaksanakan kegiatan PKM yang direncanakan. Melalui koordinasi tersebut diputuskan bahwa untuk mendampingi pelaksanaan kegiatan PKM dari awal sampai akhir akan dilakukan pendampingan oleh ketua kader yaitu di wilayah Dukuh di dampingi oleh ketua kader Nurkhasanah dan wilayah Purwojatidi dampingi oleh ketua kader Siti Jumaiyah. Pertemuan yang akan dilakukan dalam pelaksanaan kegiatan PKM disepakati sebanyak 6 kali dengan waktu pertemuan 1 kali dalam 1 minggu yang meliputi: pertemuan pertama melaksanakan FGD pada hari Sabtu tanggal 5 Mei 2018. Pertemuan kedua pelatihan 1 tentang manajemen laktasi pada hari Sabtu tanggal 12 Mei 2018. Untuk pertemuan berikutnya baik Mitra I maupun Mitra II menginginkan pertemuan dilakukan setiap hari minggu, sehingga pertemuan ketiga pelatihan 2 tentang manajemen nutrisi masa laktasi pada hari Minggu 13 Mei 2018, pertemuan keempat pelatihan 3 tentang keterampilan olah pangan dalam meningkatkan kualitas ASI dilaksanakan hari Minggu tanggal 20 Mei 2018, pertemuan kelima adalah pelatihan 4 tentang strategi menjadi edukator sebaya dilakukan pada hari Minggu tanggal 27 Mei 2018, pertemuan keenam yaitu melakukan demonstrasi untuk menjadi edukator sebaya yang dilaksanakan hari Minggu tanggal 3 Juni 2018. Selanjutnya pada tanggal 3 Juli 2018 team peneliti memberikan bantuan 1 paket media edukasi (alat peraga set) untuk memudahkan anggota Mitra melakukan edukasi sebaya terkait keterampilan olah pangan dalam menunjang kualitas ASI.

\section{Pelaksanaan Focus Group Discussion (FGD)}

Kegiatan FGD dilaksanakan hari Sabtu 5 Mei 2018. Berkaitan dengan kelanjutan program bahwa tim pelaksana menyelenggarakan pelatihan pelatihan bagi calon edukator sebaya, maka sangatlah penting untuk dlakukan pengukuran persepsi dari ibu menyusui yang telah terpilih sebagai perwakilan ibu menyusui di masing-masing wilayah hal-hal yang berkaitan dengan nutrisi masa laktasi dan upaya untuk meningkatkan kualitas ASI. Oleh karena itu tim pelaksana melakukan Focus Group Discussion (FGD) yang memiliki tujuan utama untuk mengidentifikasi pengetahuan dasar yang sudah dimiliki oleh perwakilan ibu menyusui di kedua Wilayah yaitu Dukuh dan Purwojati. Adapun hasil yang didapatkan dari proses FGD tersebut adalah sebagai berikut:

1) Pola menyusui pada saat bayi usia 0-6 bulan: Pengalaman menyusui saat bayi usia 0-6 bulan meliputi: puting susu lecet saat usia bayi 1 minggu, puting susu kecil sehingga sulit menyusui meskipun ASI lancar. Meskipun puting susu lecet disusukan terus sehingga sembuh sendiri, menyusui dilakukan pada payudara yang tidak lecet. Kondisi puting susu lecet sekitar 1 minggu. ASI pada awalnya sulit keluar, baru setelah 3 hari ASI mulai banyak, saat ASI sedikit bayi rewel. Didapatkan pengalaman ibu menyusui saat ASI belum lancar bayi dibantu dengan susu formula. Bayi diberikan ASI tidak dijadwal, bila tidur terus maka dibangunkan untuk disusui. Bayi ditambahkan susu formula karena merasa ASI belum lancar. Saat bayi 0-6 bulan ada yang sudah diberi makanan pisang hijau dengan alasan kotoran bayi yang berwarna hitam di awal usia bayi cepat bersih, pisang diberikan 2 kali sehari sampai kotoran bayi yang berwarna hijau bersih. Terdapat ibu yang memberi bayinya hanya ASI saja sampai usia 6 bulan.

2) Pola menyusui saat bayi usia >6-12: Saat bayi usia lebih dari 6 bulan, konsumsi ASI pada bayi mulai 
berkurang. Bayi sudah mulai diberi makanan tambahan yang dibuat sendiri oleh ibu, berupa bubur yang dilumatkan ditambah dengan sayuran, ada juga yang diberikan makanan tambahan berupa bubur instant. Saat malam hari bayi frekuensi menyusunya meningkat. Memberikan makanan tambahan 2 kali sehari yaitu pagi dan sore.

3) Keterampilan dalam mengoptimalkan ASI: Pengalaman ibu dalam mengoptimalkan produksi ASI yaitu dengan cara makan dalam porsi yang banyak terutama sayuran warna hijau dan makan diupayakan yang bergizi, minum jamu pelancar ASI, gepyokan dan sering menyusui. Terdapat ibu yang mengatakan telah diajari cara melakukan perawatan payudara saat ibu melakukan Antenatal Care, dan sudah dipraktikkan hanya utama pada langkah kompres payudara. Apabila ASI penuh dilakukan perah ASI dan ASI disimpan, dengan persepsi agar ASI selalu berproduksi.

4) Persepsi mengenal kuantitas dan kualitas ASI mencukupi kebutuhan bayi: Ibu menyusui mengatakan memberi ASI pada bayi dengan alasan mudah, murah, bayi lebih sehat. Namun juga terdapat ibu yang menyampaikan bahwa pengalaman saudara ibu menyusui menggunakan susu formula ternyata lebih sehat. Bayi yang diberikan ASI biasanya frekuensi minumnya menjadi lebih sering. ASI dikatakan banyak kalau setiap menyusui mencukupi dan jumlahnya banyak serta lancar. Menurut persepsi bu menyusui, bayi dikatakan kebutuhan minumnya cukup apabila tidak rewel dan dapat tidur dengan nyenyak.

5) Pola pengelolaan ASI bagi ibu yang beraktifitas atau bekerja: Ibu menyusui memiliki pengalaman bahwa bayi ditinggal dengan keluarga setelah berusia 2 tahun, sebelum 2 tahun bayi selalu diajak kemanapun pergi. Ibu mengatakan pekerjaan hanya ibu rumah tangga, tidak pernah bepergian untuk bekerja. Ibu menyusui mengatakan belum mengetahui bagaimana strategi mengelola ASI bila bayi ditinggal saat ibu pergi karena ada keperluan. Hal ini karena belum memiliki pengalaman terkait hal tersebut.

6) Pola konsumsi nutrisi masa menyusui: Pengalaman pola konsumsi nutrisi masa menyusui yang disampaikan saat FGD antara lain adalah: membiasakan minum jamu, makan sayur-sayuran seperti daun katu, minum jamu pelancar ASI, makan sayur dan ikan, minum jamu gepyokan (agar ASI tidak amis). Terdapat ibu menyusui yang melakukan diit mutih selama 40 hari yang berisi nasi dengan sayuran saja kadang ditambah tahu dan tempe, hanya saja makanan yang dikonsumsi dimakan dalam kondisi hambar karena tanpa diberi garam dan bumbu. Hal ini dilakukan agar luka daerah kandungan cepat sembuh. Selain itu konsumsi air dibatasi, dilarang makan buah pisang agar kandungan cepat kering. Konsumsi makanan pada ibu menyusui bertambah, baik nasi maupun sayuran dan lauk pauk, ibu menyusui melakukan pantang makan terutama saat tali pusat bayi belum lepas, yaitu pantang makan pedas dan ikan, setelah tali pusat bayi lepas ibu tidak pantang makan. Saat menyusui, jumlah makanan yang ditambahkan adalah semuanya mulai nasi, lauk pauk dan juga sayur.

7) Kebiasaan mengolah makanan saat masa menyusui: Kebiasaan tersering ibu menyusui adalah makan dengan komposisi nasi, lauk pauk dan sayur. Tidak memiliki kebiasaan makanan kudapan (snack), yang selalu dibuat adalah sayuran.

8) Kebiasaan dalam mengolah makanan yang berbahan dasar lele, terutama saat masa menyusui: Kebiasaan ibu dalam mengolah makanan yang berbahan dasar lele adalah terutama di goreng, sesekali dimasak menggunakan santan. Ibu menyusui belum terbiasa mengolah bahan dasar ikan lele menjadi olahan makanan lain.

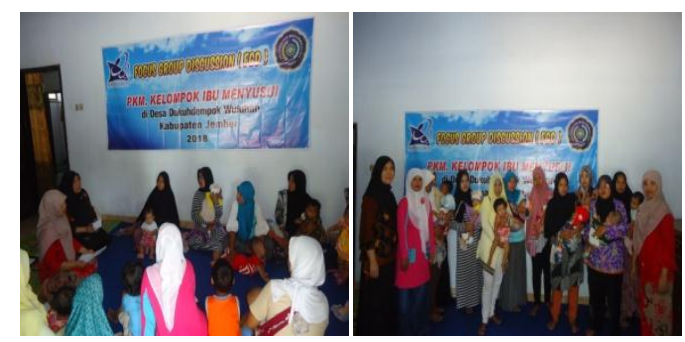

Gambar 1. Focus Group Discussion (FGD)

\section{E. Pelatihan 1 tentang manajemen laktasi.}

Tim pelaksana melakukan pelatihan 1 pada kelompok ibu menyusui pada tanggal 12 Mei 2018. Pelatihan 1 ini dilaksanakan mulai jam 09.00-12.00 WIB. Adapun topik yang dibahas pada pelatihan 1 tersebut tentang manajemen laktasi. Sebelum dan sesudah dilakukan pelatihan kelompok ibu menyusui diukur persepsinya tentang topik tersebut. Tujuan pretest untuk mngidentifikasi sejauh mana persepsi yang sudah dimiliki kelompok ibu menyusui, dan tujuan posttest adalah guna melihat perubahan persepsi setelah dilakukan pelatihan. Kelompok ibu menyusui dari kedua Mitra sangat antusias dalam mengikuti pelatihan pada kegiatan pelatihan 1 kelompok ibu menyusui pada Mitra I dan Mitra II bahwa nilai mean pengetahuan sebelum pelatihan (pretest) pada topik manajemen laktasi didapatkan nilai 57,92. Adapun nilai mean setelah pelatihan 1 (posttest) yaitu didapatkan nilai 74,17 . Selain itu pada hasil ukur tersebut didapatkan nilai $\mathrm{p}$ ( $\mathrm{p}$ value) sebesar 0,00 yang artinya ada pengaruh pelatihan 1 terhadap pengetahuan ibu menyusui tentang manajemen laktasi.
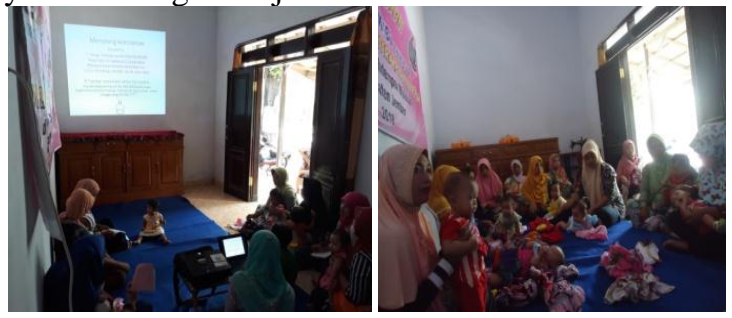

Gambar 2. Pelatihan 1(Manajemen Laktasi) 


\section{F. Pelatihan 2 tentang manajemen nutrisi masa laktasi}

Pada pelatihan selanjutnya yaitu pelatihan 2 bagi kelompok ibu menyusui tim pelaksana melakukan pada hari Minggu tanggal 13 Mei 2018. Pelatihan 2 ini juga dilaksanakan mulai jam 09.00-12.00 WIB. Topik yang dibahas pada pelatihan 2 tersebut tentang manajemen nutrisi pada masa laktasi. Sebelum dan sesudah dilakukan pelatihan kelompok ibu menyusui diukur persepsinya tentang topik tersebut. Kelompok ibu menyusui dari kedua Mitra sangat antusias dalam mengikuti pelatihan, terbukti banyaknya pertanyaan yang disampaikan oleh kelompok ibu menyusui saat memasuki sesi tanya jawab. pada kegiatan pelatihan 2 kelompok ibu menyusui pada Mitra I dan Mitra II bahwa nilai mean pengetahuan sebelum pelatihan 2 (pretest) untuk pembahasan tentang manajemen nutrisi masa laktasi didapatkan nilai 62,50. Adapun nilai mean setelah pelatihan 2 (posttest) didapatkan nilai 76,25. Hasil ukur pelatihan 2 ini juga didapatkan nilai $\mathrm{p}$ ( $p$ value) sebesar 0,00 yang artinya ada pengaruh pelatihan 2 terhadap pengetahuan ibu menyusui tentang manajemen nutrisi masa laktasi.

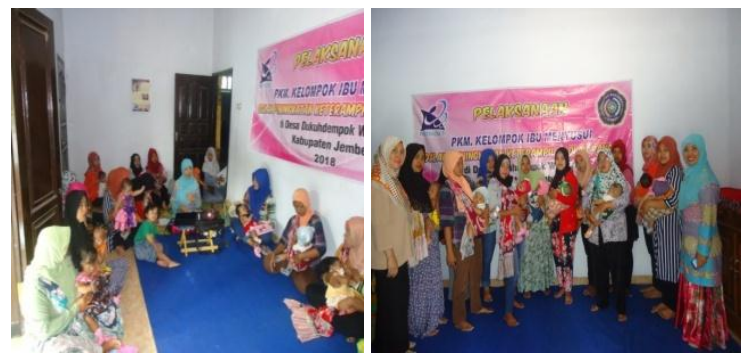

Gambar 3. Pelatihan 2 (Manajemen Nutrisi Masa Laktasi)

\section{G. Pelatihan 3 tentang keterampilan olah pangan dalam} meningkatkan kualitas ASI

Pelatihan 3 bagi kelompok ibu menyusui tim pelaksana melakukan pada hari Minggu tanggal 20 Mei 2018. Pelatihan 3 ini juga dilaksanakan mulai jam 09.00-12.00 WIB. Topik yang dibahas pada pelatihan 3 adalah tentang keterampilan olah pangan dalam meningkatkan kualitas ASI. Sebelum dan sesudah dilakukan pelatihan kelompok ibu menyusui diukur kemampuan melakukan keterampilan olah pangan yang berbahan dasar lele. Metode pelatihan yang dilakukan dalam bentuk ceramah, demonstrasi dan redemonstrasi. Kelompok ibu menyusui dari kedua Mitra sangat responsif dalam mengikuti pelatihan, terbukti saat melakukan redemonstrasi olah pangan yang berbahan dasar lele, peserta dapat mendemonstrasikan sesuai arahan yang telah disampaikan. pada kegiatan pelatihan 3 kelompok ibu menyusui pada Mitra I dan Mitra II bahwa nilai mean kemampuan keterampilan olah pangan dalam menunjang kualitas ASI sebelum pelatihan 3 (pretest) didapatkan nilai 57,08. Adapun nilai mean setelah pelatihan 3 (posttest) didapatkan nilai 77,08. Hasil ukur pengaruh pelatihan 3 ini didapatkan nilai $\mathrm{p}$ ( $p$ value $)$ sebesar 0,00 yang artinya ada pengaruh pelatihan 3 terhadap kemampuan ibu menyusui tentang keterampilan olah pangan dalam menunjang kualitas ASI.

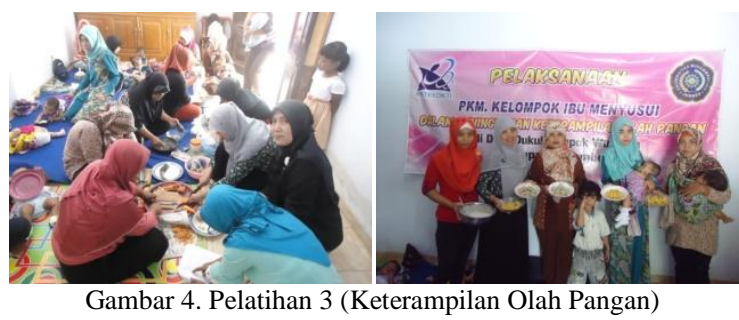

\section{H. Pelatihan 4 tentang strategi menjadi edukator sebaya.}

Melalui pelatihan 4 bagi kelompok ibu menyusui tim pelaksana melakukan pada hari Minggu tanggal 27 Mei 2018. Pelatihan 4 ini juga dilaksanakan mulai jam 09.0012.00 WIB. Topik yang dibahas pada pelatihan 4 yaitu tentang strategi menjadi edukator sebaya. Sebelum dan sesudah dilakukan pelatihan kelompok ibu menyusui diukur pengetahuan tentang strategi menjadi edukator sebaya. Kelompok ibu menyusui dari kedua Mitra sangat aktif dalam mengikuti pelatihan. pada kegiatan pelatihan 4 kelompok ibu menyusui pada Mitra I dan Mitra II bahwa nilai mean tentang strategi menjadi konselor sebaya sebelum pelatihan 4 (pretest) didapatkan nilai 56,25. Adapun nilai mean setelah pelatihan 4 (posttest) didapatkan nilai 75,00. Hasil ukur pengaruh pelatihan 4 ini didapatkan nilai $\mathrm{p}$ ( $p$ value) sebesar 0,00 yang artinya ada pengaruh pelatihan 4 terhadap pengetahuan ibu menyusui tentang strategi menjadi edukator sebaya.

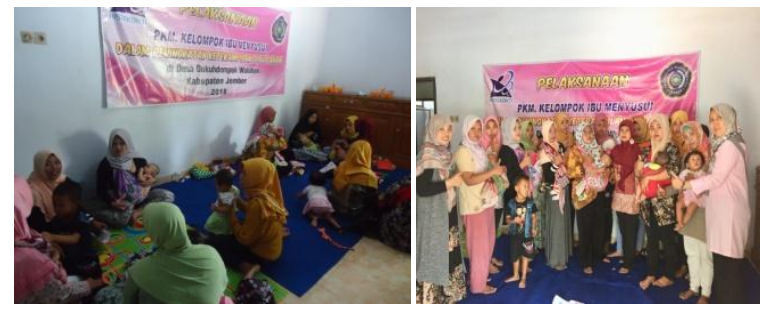

Gambar 5. Pelatihan 4 (Edukator Sebaya)

\section{Demonstrasi menjadi edukator sebaya.}

Kegiatan demonstrasi untuk menjadi edukator sebaya yang dilakukan oleh kelompok ibu menyusui pada Mitra I dan II dilakukan pada hari Minggu tanggal 3 Juni 2018. Demonstrasi ini dilaksanakan mulai jam 10.00-14.00 WIB. Pada kegiatan ini sebelum dan sesudah demonstrasi ini diukur kemampuannya menjadi edukator sebaya. Kelompok ibu menyusui dari kedua Mitra bersemangat dalam melakuak demonstrasi. pada kegiatan demonstrasi menjadi edukator sebaya bahwa pengetahuan ibu menyusui tentang cara meningkatkan kualitas ASI sebelum demontrasi sebagi edukator sebaya (pretest) didapatkan nilai mean 61,25 Adapun nilai mean setelah demonstrasi (posttest) didapatkan nilai 75,42. Hasil ukur pengaruh pelatihan 4 ini didapatkan nilai $\mathrm{p}$ ( $p$ value) sebesar 0,00 yang artinya ada pengaruh pengaruh demonstrasi sebagai edukator sebaya 
terhadap pengetahuan ibu menyusui tentang cara meningkatkan kualitas ASI pada Mitra I dan II.

Setelah berakhirnya kegiatan kelima selanjutnya tim pelaksana melakukan pendampingan pada kelompok ibu menyusui dalam melakukan edukator pada kelompok sebayanya. Guna memudahkan proses edukasi, maka tim pelaksana memberikan bantuan seperangat media untuk meudahkan dalam pemberian edukasi, yang dilakukan pada tanggal 3 juli 2018.

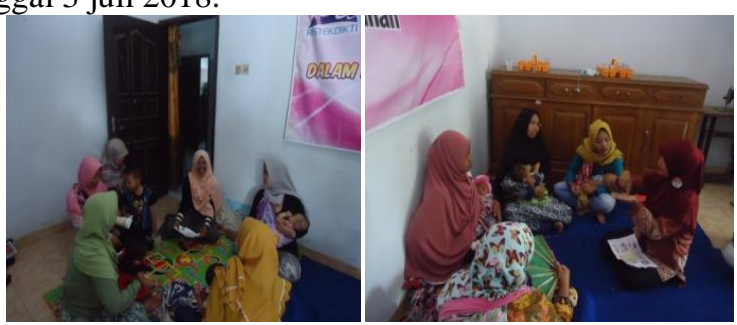

Gambar 6. Demosntrasi Edukator Sebaya

\section{J. Program PKM yang ditransfer pada Mitra I dan Mitra II}

Berkaitan dengan kegiatan program PKM yang ditransfer pada kedua Mitra yaitu Mitra I dan II sebagai kelompok ibu menyusui dalam meningkatkan kemampuan keterampilan olah pangan dalam menunjang kualitas ASI tergambar pada bagan di bawah ini:

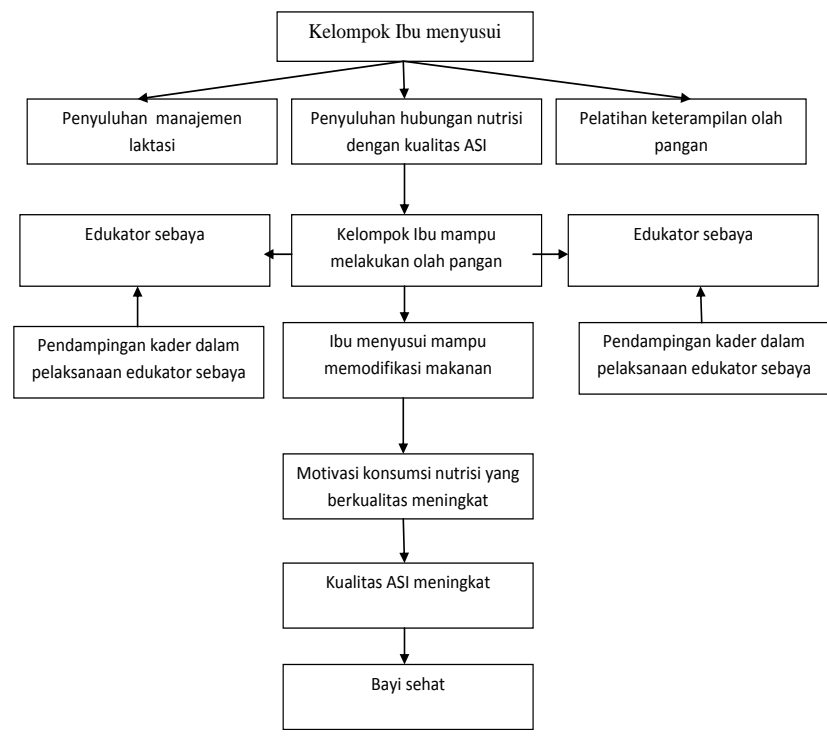

Bagan 1. Program PKM Yang Ditransfer Kepada Mitra I dan II di Wilayah Dukuh dan Purwojati Desa Dukuhdempok Kecamatan Wuluhan Jember
ASI merupakan makanan yang tepat dan utama bagi bayi usia 0-6 bulan. Oleh karena itu makanan bayi tersebut sangat tergantung dengan asupan makanan yang dikonsumsi oleh ibu menyusui. Bila kualitas ASI baik, maka nutrisi bayi akan baik pula (Indriyani, Asmuji dan Wahyuni, 2016). Namun faktanya kelompok ibu menyusui kadang masih mengalami kendala dalam menyiaplkan kualitas ASI yang baik, faktor diantaranya adalah karena: pemahaman yang belum optimal dalam hal manajemen laktasi, pentingnya hubungan nutrisi terhadap kualitas ASI, keterampilan olah pangan dalam menyiapkan gizi seimbang selama laktasi belum optimal. Bila kelompok ibu menyusui yang dalam hal ini sebagai Mitra sudah memiliki kemampuan tersebut di atas, makan akan berdampak kemampuan oleh pangan menjadi meningkat, lebih bervariasi dalam menyediakan sajian nutrisi, sehingga motivasi konsumsi yang mengandung komponen penting terutama protein bisa meningkat. Kemampuan Mitra dalam hal olah pangan ini dapat disebarkan dengan Mitra berperan sebagai edukator sebaya bagi kelompoknya. Selama peran tersebut kader kesehatan akan melakukan pendampingan agar Mitra berperan dengan optimal.

Program PKM yang ditransfer pada Mitra pada tahapan olah pangan ini adalah dilakukan dengan mengambil contoh makanan yang berasal dari bahan dasar ikan lele. bahan dasar ini dipilih dengan alasan selain gurih, lele merupakan bahan dasar yang mudah didapat, murah dan digemari masyarakat, serta mengandung unsur gizi yang baik. Unsur gizi tersebut terutama tinggi protein, dan asam amino omega 3, rendah lemak, mengandung kadar fosfor, magnesium,zink, kalsium, zat besi dan kalium cukup tinggi (porsi ikan lele mengandung 15,6 gram protein), sumber vitamin B12 (porsi lele sudah memenuhi kebutuhan $40 \%$ vitamin B 12), rendah merkuri, sehinga sangat tepat diberikan untuk ibu yang sedang menyusui juga dapat sebagai penunjang penyembuhan luka bagi ibu menyusui karena dampak dari persalinan. Tim pengusul akan melakukan pelatihan keterampilan olah pangan yang bagi Mitra dengan bahan dasar tersebut menjadi contoh menu 5 jenis hasil olahan yaitu: a) nugget lele, b) lele fillet goreng tepung, c) lele rempah kelapa daun kunyit, d) lele kuning asam pedas dan e) lele panggang nusantara

Terkait bagan model PKM yang ditransfer pada kedua Mitra memiliki tujuan agar ibu menyusui memiliki kemampuan dalam meningkatkan perilaku menyusui baik pada aspek kuantitas maupun kualitas ASI dengan strategi meningkatnya persepsi terkait manajemen laktasi dan kemampuan keterampilan olah pangan dengan bahan dasar lele untuk menunjang kualitas ASI. Semua tahapan dalam mentranfer kegiatan PKM tersebut telah dilakukan. Pendekatan model mengikuti prosedur tehnis yang telah ditetapkan untuk mencapai luaran. Kegiatan tersebut meliputi tahapan koordinasi, sosialisasi, pembentukan kelompok ibu menyusui dari kedua Mitra, pelatihan bagi ibu menyusui, dan demonstrasi kelompok ibu menyusui menjadi edukator sebaya. Selama melaksanakan kegiatan 
inti tersebut utamanya dilaksanakan pada hari Minggu, dengan maksud Mitra I dan Mitra II meiliki waktu yang luang.

Melalui tahapan-tahapn pendekatan model PKM yang ditransfer ke Mitra tersebut tim pelaksana mendapatkan dukungan yaitu baik Mitra I maupun Mitra II. Kedua Mitra sangat antusias dalam mengikuti kegiatan, kelompok ibu menyusui yang didampingi kader dari kedua wilayah Mitra sangat disiplin dan antusias mengikuti jadwal yang telah ditetapkan bersama, Puskesmas juga memfasilitasi dan mensupport kegiatan ini. Hal ini karena aktifitas ini memiliki sinergisme dengan program kesehatan ibu dan anak (KIA) yang memiliki tujuan akhir (outcome) untuk mendukung penurunan AKI dan AKB.

\section{KESIMPULAN}

- Tahapan koordinasi dn sosialisasi Program Kemitraan Masyarakat (PKM) pada kelompok ibu menyusui dapat dilaksanakan dengan baik sesuai rencana. Baik Mitra I dan Mitra II sangat responsif untuk mendukung kegiatan pengabdian masyarakat ini.

- Tahapan untuk pembentukan kelompok ibu menyusui sebagai edukator sebaya pada Mitra I dan Mitra II telah dilaksanakan, masing-masing Mitra memiliki jumlah edukator sebanyak 6 orang.

- Guna menguatkan pemahaman edukator dari kelompok ibu menyusui ini tentang peran dan fungsinya maka dilakukan kegiatan pelatihan yang diselenggarakan dengan 4 kali pelatihan dan dilanjutkan dengan demonstrasi sebagai edukator sebaya pada ibu menyusui. Untuk menunjang kebutuhan pelatihan tim pelaksana juga menyediakan leaflet, booklet dan modul pelatihan. Adapun pada kegiatan pelatihan 3 tentang keterampilan olah pangan dalam meningkatkan kualitas ASI dikuatkan dengan demonstrasi dalam mengolah makanan yang berbahan dasar lele menjadi menu-menu yang berbeda dari cara mengolah lele yang umumnya cenderung digoreng saja. Pada pelatihan ke 4 tentang strategi menjadi edukator sebaya, dikuatkan pada kegiatan ke 5 dipertemuan selanjutnya yaitu demonstrasi sebagai edukator sebaya.

- Selama pelatihan pada kelompok ibu menyusui tim pelaksana telah melakukan pengukuran pencapaian sebagai dampak pelatihan yaitu dalam bentuk pretest dan posttest, juga redemonstrasi sebagai edukator sebaya. Adapun pencapaian kognitif dapat disimpulkan bahwa ada peningkatan pengetahuan antara sebelum dan sesudah pelatihan, baik pada pelatihan 1,2,3,4 maupun saat demonstrasi sebagai edukator sebaya.

- Guna menoptimalkan keberhasilan program implementasi tim pelaksana juga telah melakukan pendampingan pada kelompok ibu menyusui. Sebaiknya program ini dilakukan terus secara berkelanjutan.

\section{UCAPAN TERIMAKASIH}

Direktorat Riset dan Pengabdian Kepada Masyarakat. Kementerian Riset, Teknologi, dan Pendidikan Tinggi yang telah mendanai kegiatan ini.

\section{DAFTAR PUSTAKA}

[1] Anggorowati \& Nuzulia, F. (2013). Hubungan antara Dukungan Keluarga dengan Pemberian ASI Eksklusif pada Bayi di Desa Bebengan Kecamatan Boja Kabupaten Kendal. Jurnal Keperawatan Maternitas Vol. 1 No.1; 1-8

[2] Alodokter. (2015). Tidak Sedikit Manfaat Ikan Lele. www.alodokter.com

[3] Dinas Kesehatan Kabupaten Jember. (2015). Laporan Tahunan Dinas Kesehatan Kabupaten Jember.

[4] Hamilton, P.M. (2010). Dasar-dasar Keperawatan Maternitas. Edisi 7. Alih Bahasa: Asih, G.Y. Jakarta: EGC

[5] Indriyani D., Asmuji. Dan Wahyuni, S., (2016). Edukasi Postnatal dengan Pendekatan Family Centered Maternity Care (FCMC). Yogyakarta: Trans Medika

[6] Indriyani D. dan Azza, A. (2017). Survey perilaku konsumsi nutrisi pada ibu menyusui dan ASI Ekslusif di Kabupaten Jember. LPPM. Universitas Muhammadiyah Jember 